Article

\title{
Sodium Content of Processed Foods Available in the Mexican Market
}

\author{
Claudia Nieto $₫$, Lizbeth Tolentino-Mayo $₫$, Catalina Medina $₫$, Eric Monterrubio-Flores $₫$, \\ Edgar Denova-Gutiérrez $(\mathbb{D}$ and Simón Barquera $*$ (D)
}

Centro de Investigación en Nutrición y Salud, Instituto Nacional de Salud Pública, Cuernavaca 62100, Mexico; claudia.nieto@insp.mx (C.N.); mltolentino@insp.mx (L.T.-M.); catalina.medina@insp.mx (C.M.); eric@insp.mx (E.M.-F.); edgar.denova@insp.mx (E.D.-G.)

* Correspondence: sbarquera@insp.mx; Tel.: +52-777-329-3017

Received: 23 October 2018; Accepted: 17 December 2018; Published: 19 December 2018

\begin{abstract}
Background: Sodium intake is related to several adverse health outcomes, such as hypertension and cardiovascular diseases. Processed foods are major contributors to the population's sodium intake. The aim of the present study was to determine sodium levels in Mexican packaged foods, as well as to evaluate the proportion of foods that comply with sodium benchmark targets set by the United Kingdom Food Standards Agency (UK FSA) and those set by the Mexican Commission for the Protection of Health Risks (COFEPRIS). We also evaluated the proportion of foods that exceeded the Pan American Health Organization (PAHO) targets. Methods: This was a cross-sectional study that comprised data collected from the package of 2248 processed foods from selected supermarkets in Mexico. Results: Many processed food categories contained an excessive amount of sodium. Processed meats, ham, bacon and sausages, had the highest concentrations. The proportion of foods classified as compliant in our sample was lower for international targets (FSA UK and PAHO) compared to the Mexican COFEPRIS criteria. Conclusions: These data provided a critical baseline assessment for monitoring sodium levels in Mexican processed foods.
\end{abstract}

Keywords: sodium; sodium targets; food industry; diet

\section{Introduction}

Sodium intake is related to several adverse health outcomes, such as hypertension, cardiovascular diseases, and death [1-4]. In 2010, approximately 1.65 million cardiovascular deaths in the world were attributed to a salt intake above the limit of $5 \mathrm{~g}$ a day [3] and in some areas in North/South America, this was the 9th to 15th leading cause of premature death. In Mexico, the prevalence of hypertension in adults reached 31.5\% [5]. Furthermore, cardiovascular diseases were the first cause of death in the country [6]. The World Health Organization (WHO) recommends that the intake of salt should be less than 5 g per day [7]. In 2013, the Global Action Plan for the Prevention and Control of Non-Communicable Diseases set a target to reduce the population intake of sodium by $30 \%$ [8], since it is considered one of the most cost-effective interventions to improve population health [9]. Due to sodium's effect on the population's health, several countries have introduced strategies to reduce it, including health promotion campaigns, taxes, food labelling, consumer education, and public health interventions [10,11]. In Mexico, some strategies like removing saltshakers from tables of restaurants and reducing sodium in bread have been implemented $[12,13]$.

Processed foods are major contributors to the population's dietary salt intake [14-17]; therefore, lowering sodium in packaged foods can be an important intervention to reduce it. In the Mexican population, the main dietary sources of sodium are breads, meats, pizzas, sandwiches, cheese, and some packaged foods such as soups, rice, and snacks [18]. A recent study found that ready to eat 
breakfast cereals were high in sodium content [19]. Since 36\% of the total energy intake of the Mexican diet comes from processed and ultra-processed foods [20], an assessment of current sodium content is key to monitoring processed foods and encouraging reformulation. Some institutions have been working to establish targets in order to monitor and evaluate the content of sodium. Those institutions are: The Food Standard Agency (FSA) in United Kingdom (UK), the Federal Commission for Protection against Health Risks (COFEPRIS, by its acronym in Spanish) in Mexico, and the Pan American Health Organization (PAHO) in the Pan-American region.

In this context, the UK FSA established targets for 2017 aiming for further reduction of sodium content [21]. They also recognized the progress made by the UK food industry in 2013; nevertheless, they acknowledged the potential to further reduce the salt content in processed foods with the new targets [22]. In Mexico, as a part of a policy package to fight obesity and chronic diseases, the Mexican government, specifically COFEPRIS, implemented a voluntary strategy for packaged foods. This voluntary legislation consisted of obtaining the nutritional stamp endorsed by the Ministry of Health if food manufacturers accomplish nutrients criteria. Such stamp aimed to indicate if a product is healthy for regular consumption. This legislation, approved by the Ministry of Health in 2014, established cut-off points regarding the maximum levels of energy, sodium, saturated fat, and sugar allowed in commonly consumed foods [23]. Finally, in las Americas the PAHO brought together a consortium of governments, civil society, and food companies (the Salt Smart Consortium) to set maximum targets (upper limits) for sodium levels for 11 food categories to be achieved by December of 2016. The technical advisory group (TAG) used their experiences and lessons learned to provide guidance on establishing national initiatives that encourage food companies to reformulate their products [24]. The food categories considered were: Bread, soups, mayonnaise, biscuits and cookies, cake, meats, breakfast cereals, cheese, processed cheese products, and cheese spreads, butter/dairy spreads and margarine, snacks, pasta, and condiments.

To date, Mexico does not have a monitoring system to evaluate the sodium content of processed foods. Furthermore, Mexico does not have an assessment that shows compliance with international, regional, and local targets. Thus, the main objectives of the study were to determine sodium levels in Mexican packaged foods and to evaluate the proportion of foods that comply with sodium benchmark targets set by the UK FSA and COFEPRIS. We also evaluated the proportion of foods that exceeded the PAHO targets.

\section{Materials and Methods}

\subsection{Study Design}

This cross-sectional study comprised data collected from July to December of 2015. Data were collected from selected supermarkets in the country.

A sampling strategy was used to identify the largest and most densely populated cities in the country (Mexico City, Guadalajara, Queretaro, Monterrey, Hermosillo, and Cuernavaca) [25]. Our sample frame was based on a list of all supermarkets in each city, and those supermarkets were mapped using a geo-reference system to determine the Basic Geostatistical Areas (AGEB by its acronym in Spanish) where they were located. AGEB are a proxy-estimation of socio-demographic characteristics of the area in each city, which delimitates urban areas with 25,000 inhabitants or more, and are used to identify specific conditions such as living, commercial, and industrial usage. The supermarkets in each AGEB were randomly and proportionally selected to the distribution of three levels of marginalization defined by the National Institute of Statistics and Geography (low, middle and high) [26]. The visited stores were hypermarkets, supermarkets, membership food stores, and convenience stores. Those stores were: 7 Eleven, Walmart, Bodega Aurrera, Bodega Express, Chedraui, City market, Comercial Mexicana, Cotsco, Extra, Fresko, Ley, Mega Comercial, Mini-super, Oxxo, Sams, Santa Fe, Smart, Soriana, Sumesa, Superama, Vimark, Waldos, and grocery stores that are not part of a franchise. Those together represent approximately 70\% of the Mexican market share [27]. 
We did not have any store losses since the permits were given by the legal department of each main food retail chain prior to the data collection. All available food products at the time in the stores' aisles were included. This sampling allowed an extensive coverage of available food products in Mexico.

Photographs of the labelling and package of processed foods were taken from main food retail chains in the country. One fieldwork coordinator, four trained fieldworkers with broad experience in survey data collection, and five nutrition students were trained by researchers of the Mexican National Institute of Public Health following the International Network for Food and obesity/non-communicable diseases, Research, Monitoring and Action support (INFORMAS) protocol of food labelling [28]. The personnel who collected the data followed a standardized operation procedure according to Kanter et al. [29].

Nutrition content information from photographs were captured into an excel spreadsheet. The fieldworker coordinator revised the completeness and accuracy of the data. We randomly selected a subsample of 300 products to check the captured data against the photographs taken. The database included the following information: Product name, brand, price, claims, serving size, nutrition content, and location of supermarket. In the case of exact duplicates, the most recently entered product was used. Information from $(n=2248)$ different food products was analyzed. Sodium content was recorded in $\mathrm{mg}$ per portion and then converted into $\mathrm{mg} / 100 \mathrm{~g}$. Food categories and subcategories were defined based on the UK FSA and on the PAHO criteria. The UK FSA targets for sodium were lower compared to the COFEPRIS targets. Some examples are: Ham (650 mg sodium vs. $800 \mathrm{mg}$ sodium), breakfast cereals ( $235 \mathrm{mg}$ sodium vs. $500 \mathrm{mg}$ sodium), and biscuits ( $220 \mathrm{mg}$ sodium vs. $450 \mathrm{mg}$ sodium). There are two types of averages used within the UK FSA targets. The first is a processing average (p) that is used to account for ranges of salt levels that occur in a single product (e.g., bacon and mozzarella cheese). The second is a range average ( $r$ ) which is used to account for a range of different flavors (e.g., standard potato crisps) covered by a single target. All range averages were calculated on a sales weighted basis. Reduced mayonnaise refers to those mayonnaises that are reduced fat or reduced calories; nevertheless, COFEPRIS does not have a target for reduced mayonnaise [21]. Similarly, PAHO targets were lower compared to COFEPRIS Mexican targets. The PAHO has supported sodium reduction policies in the Americas and proposed inaugural regional targets for several food categories in 2014 [24]. These targets were based on national targets for sodium reduction in the region, either voluntary or regulatory. A more stringent target was also proposed, based on the lowest targets in the region, in order to support countries with their national sodium reduction policies and to improve their current policies [30].

\subsection{Statistical Analysis}

The database was imported to STATA format to be cleaned. First, we identified outliers of the sodium content by each food category or subcategory. When an extreme value was found, we checked against photographs of processed products to see if the value was correct. Additionally, we randomly checked the sodium content against the photographs of the products to ensure accuracy.

First, normal distribution of the variables was calculated. Mean and standard deviations of sodium content $(\mathrm{mg} / 100 \mathrm{~g})$ of food categories and subcategories were calculated. Percentiles were also calculated since most of the data were skewed. We calculated the proportion of compliant food products by the FSA benchmarks and COFEPRIS cut-off points when available. Differences in the proportion of compliant food categories and subcategories between the UK FSA targets and COFEPRIS criteria were explored using tests of proportions. For all the analyses, significance was established when $p<0.05$. All analyses were performed using STATA version 14 (StataCorp, College Station, TX, USA).

\subsection{Ethical Approval}

This study was evaluated and approved by the Research, Ethics and Biosafety Committees of the National Institute of Public Health of Mexico (ethical approval number: 1275). Before conducting the 
study, the research team asked for permission from the supermarket manager to access the stores and take photos of processed foods available.

\section{Results}

This analysis included 2248 food items from 12 food groups. Table 1 shows the mean sodium content in $\mathrm{mg}$ per $100 \mathrm{~g}$. The food groups with the highest sodium content were: Ham $(1255.1 \mathrm{mg} / 100 \mathrm{~g})$, bacon $(1027.4 \mathrm{mg} / 100 \mathrm{~g})$, sausages $(883.9 \mathrm{mg} / 100 \mathrm{~g})$, reduced mayonnaise $(868.9 \mathrm{mg} / 100 \mathrm{~g})$, processed cheese $(862.7 \mathrm{mg} / 100 \mathrm{~g})$, and mayonnaise $(751.7 \mathrm{mg} / 100 \mathrm{~g})$. There was high variability in sodium levels across several product categories including: Soups (220.0-5165.7 mg/100 g), pasta $(4.2-3480.0 \mathrm{mg} / 100 \mathrm{~g})$, and biscuits $(4.0-2778.8 \mathrm{mg} / 100 \mathrm{~g})$. In contrast, there was less variability in the sodium content of standard potato crisps $(400.0-560.0 \mathrm{mg} / 100 \mathrm{~g})$ and mozzarella cheese (303.64-674.0 mg/100 g). Butter and cake had the lowest sodium content with $129.7 \mathrm{mg} / 100 \mathrm{~g}$ and $263.1 \mathrm{mg} / 100 \mathrm{~g}$ respectively.

Table 1. Sodium content of processed food groups and subgroups available in the Mexican market $(\mathrm{mg} / 100 \mathrm{~g})(N=2248)$.

\begin{tabular}{|c|c|c|c|c|c|c|c|c|c|}
\hline Food Group & Subgroup & $n$ & Min & Max & Mean & SD & p25 & p50 & p75 \\
\hline \multirow{2}{*}{ Meat Products } & Ham & 43 & 500 & 2900 & 1255 & 738 & 745 & 995 & 1580 \\
\hline & Sausages & 82 & 70 & 1500 & 884 & 204 & 807 & 897 & 982 \\
\hline Bread & & 215 & 133 & 1500 & 552 & 215 & 390 & 447 & 616 \\
\hline Breakfast Cereals & Breakfast cereals & 404 & 0 & 1062 & 298 & 223 & 67 & 323 & 480 \\
\hline \multirow{2}{*}{ Cheese } & Processed cheese & 60 & 210 & 2667 & 863 & 421 & 600 & 780 & 1149 \\
\hline & Fresh cheese * & 35 & 14 & 970 & 498 & 209 & 363 & 568 & 615 \\
\hline Butter & Butter & 40 & 0 & 740 & 130 & 231 & 0.7 & 9.02 & 198 \\
\hline \multirow{3}{*}{ Fat Spreads } & Margarine & 22 & 400 & 920 & 586 & 182 & 440 & 530 & 735 \\
\hline & Mayonnaise & 29 & 536 & 1250 & 752 & 218 & 570 & 625 & 932 \\
\hline & Reduced mayonnaise * & 12 & 680 & 1200 & 869 & 139 & 757 & 883 & 913 \\
\hline Soups & & 84 & 220 & 5165 & 723 & 803 & 350 & 594 & 690 \\
\hline Pizzas & & 51 & 272 & 934 & 483 & 119 & 407 & 473 & 547 \\
\hline Biscuits & & 594 & 4 & 2778 & 297 & 206 & 162 & 276 & 388 \\
\hline Pasta & & 161 & 4 & 3480 & 804 & 827 & 74 & 643 & 1652 \\
\hline
\end{tabular}

${ }^{*}$ Food groups or subgroups that had a normal distribution $(p>0.05)$.

Processed foods in the Mexican market were also classified as compliant and non-compliant according to two profiling systems: The UK FSA targets and the COFEPRIS criteria. Overall, $61 \%$ complied with COFEPRIS target, while only $32 \%$ of foods complied with the FSA target (Figure 1). In other words, twice the amount of food products complied with the COFEPRIS target than with UK FSA criteria.

a)

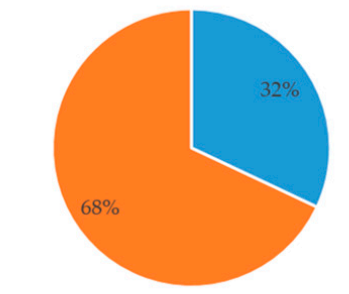

- Comply with FSA target $\quad$ = Do not comply b)

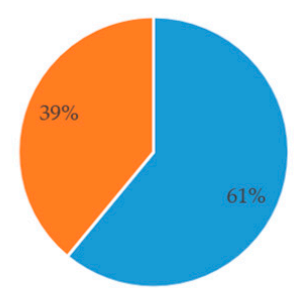

" Comply with COFEPRIS sodium target " Do not comply

Figure 1. (a) Proportion of packaged foods meeting and exceeding the Food Standard Agency (FSA) sodium benchmark targets. (b) Proportion of packaged foods meeting and exceeding the Federal Commission for Protection against Health Risks (COFEPRIS by its acronym in Spanish) sodium targets $(n=2248)$. 
Table 2 shows the proportion of packaged foods that comply with sodium targets from the UK FSA and COFEPRIS. The highest proportion of foods meeting the UK FSA targets were butter (93\%), salt and vinegar crisps $(71 \%)$, and bacon $(62 \%)$, whereas mayonnaise $(0 \%)$, reduced mayonnaise $(0 \%)$, and soups $(2 \%)$ had the lowest compliance. On the other hand, the highest proportion of foods meeting the COFEPRIS criteria were mozzarella cheese (100\%), fresh cheese (94\%), and butter (93\%). The lowest compliance levels were for sausages $(22 \%)$, soups $(24 \%)$ and ham $(28 \%)$.

Table 2. Percentage of compliance of 2248 processed foods with UK FSA targets and COFEPRIS targets.

\begin{tabular}{|c|c|c|c|c|c|c|c|}
\hline Food Group & Subgroup & $n$ & $\begin{array}{c}\text { UK FSA } \\
\text { Target } \\
(\mathrm{mg} / 100 \mathrm{~g})\end{array}$ & $\begin{array}{l}\text { COFEPRIS } \\
\text { Target } \\
(\mathrm{mg} / 100 \mathrm{~g})\end{array}$ & $\begin{array}{l}\% \text { of Compliance } \\
\text { with FSA Target }\end{array}$ & $\begin{array}{c}\% \text { of Compliance } \\
\text { with COFEPRIS } \\
\text { Target }\end{array}$ & $p$ value \\
\hline \multirow[t]{3}{*}{ Meat Products } & Bacon & 21 & 1150 & NA & 62 & NA & - \\
\hline & Ham & 43 & $650(\mathrm{p})$ & 800 & 14 & 28 & 0.5 \\
\hline & Sausages & 82 & $650(\mathrm{p})$ & 800 & 7 & 22 & 0.4 \\
\hline Bread & & 215 & $360(\mathrm{r})$ & 500 & 14 & 61 & 0.001 \\
\hline $\begin{array}{l}\text { Breakfast } \\
\text { Cereals }\end{array}$ & Breakfast cereals & 404 & $235(r)$ & 500 & 37 & 78 & 0.001 \\
\hline \multirow[t]{3}{*}{ Cheese } & Processed cheese & 60 & $650(r)$ & 800 & 32 & 58 & 0.06 \\
\hline & Fresh cheese & 35 & $200(r)$ & 800 & 14 & 94 & 0.001 \\
\hline & Mozzarella & 17 & $540(\mathrm{p})$ & 900 & 47 & 100 & 0.03 \\
\hline Butter & Butter & 40 & $590(\mathrm{r})$ & 500 & 93 & 93 & 0.5 \\
\hline \multirow[t]{2}{*}{ Fat Spreads } & Margarine & 22 & $425(\mathrm{r})$ & 500 & 18 & 50 & 0.67 \\
\hline & Mayonnaise & 29 & $500(\max )$ & 750 & 0 & 59 & - \\
\hline \multirow[t]{3}{*}{$\begin{array}{l}\text { Crisp and } \\
\text { Snacks }\end{array}$} & $\begin{array}{c}\text { Standard potato } \\
\text { crisps }\end{array}$ & 5 & $525(r)$ & 450 & 60 & 60 & 0.5 \\
\hline & $\begin{array}{l}\text { Extruded and } \\
\text { sheeted snacks }\end{array}$ & 234 & $680(\mathrm{r})$ & NA & 40 & NA & - \\
\hline & $\begin{array}{l}\text { Salt and Vinegar } \\
\text { products }\end{array}$ & 7 & $750(\mathrm{r})$ & NA & 71 & NA & - \\
\hline Cakes & & 132 & $170 \mathrm{mg}(\mathrm{r})$ & 450 & 23 & 89 & 0.001 \\
\hline Biscuits & & 594 & $220(\mathrm{r})$ & 450 & 36 & 85 & 0.001 \\
\hline Pasta & & 161 & $200(r)$ & 500 & 40 & 64 & 0.01 \\
\hline
\end{tabular}

FSA targets: There are two types of averages used within the targets table. Average (p) used to account for ranges of salt levels that occur in a single product and average ( $\mathrm{r}$ ) which is used to account for a range of different flavors. * Reduced mayonnaise: Refers to those mayonnaises that have reduced fat or reduced calories.

\subsection{Comparison UK FSA vs. COFEPRIS}

From the 43 types of ham collected, 14\% complied with the UK FSA target (650 $\mathrm{mg}$ of sodium/100 g), while $28 \%$ complied with COFEPRIS ( $800 \mathrm{mg}$ of sodium/100 g). Sausages faced a similar situation; $7 \%$ complied with the FSA target and 22\% complied with COFEPRIS. No statistically significant differences were found for those two subgroups $(p>0.05)$. Among the different kinds of bacons assessed, only $38 \%$ of different bacons are above the UK FSA target whereas COFEPRIS does not have a cut-off point. Bread had $14 \%$ of products complying with UK FSA targets compared to $61 \%$ complying with COFEPRIS criteria $(p<0.001)$. For breakfast cereals, $37 \%$ complied with UK FSA, while 78\% complied with COFEPRIS $(p<0.001)$. For mayonnaise and for reduced mayonnaise none of the products complied with the UK FSA target, while the proportion of mayonnaise that complied with the COFEPRIS criteria was $59 \%$. The only food subgroup that had the same proportion of compliance for both targets was standard potato crisps $(60 \%)$. Even though cakes had one of the lowest mean sodium contents, only $23 \%$ complied with UK FSA target (170 mg of sodium $/ 100 \mathrm{~g}$ ) and $89 \%$ complied with COFEPRIS sodium criteria $(450 \mathrm{mg}$ of sodium $/ 100 \mathrm{~g})(p<0.001)$ (Table 2$)$.

\subsection{PAHO Sodium Reduction Targets}

Finally, Table 3 shows the food categories and subcategories that exceed the regional and lower targets set by the PAHO. Soups were the category with the highest proportion above the regional target $(73 \%)$, while butter complied the most with $100 \%$ of the regional target established by PAHO. 
Meats were the category with the highest proportion above the lower target (91\%). Butter only had 8\% above the lower target. Snacks and breads also had great proportions above the PAHO regional target, $35 \%$ and $29 \%$ respectively. Soups and snacks had great proportions above the lower target, $(88 \%$ and $83 \%$, respectively). The food categories that complied the most with the regional targets were: Butter $(100 \%)$, meats $(98 \%)$, and breakfast cereals $(96 \%)$. However, lower targets were harder to meet, being butter $(92 \%)$, breakfast cereals $(78 \%)$, and pasta $(77 \%)$ who came closest to meeting the targets.

Table 3. Percentage of 1977 processed foods that exceed the regional and lower sodium reduction targets set by the Pan American Health Organization (PAHO).

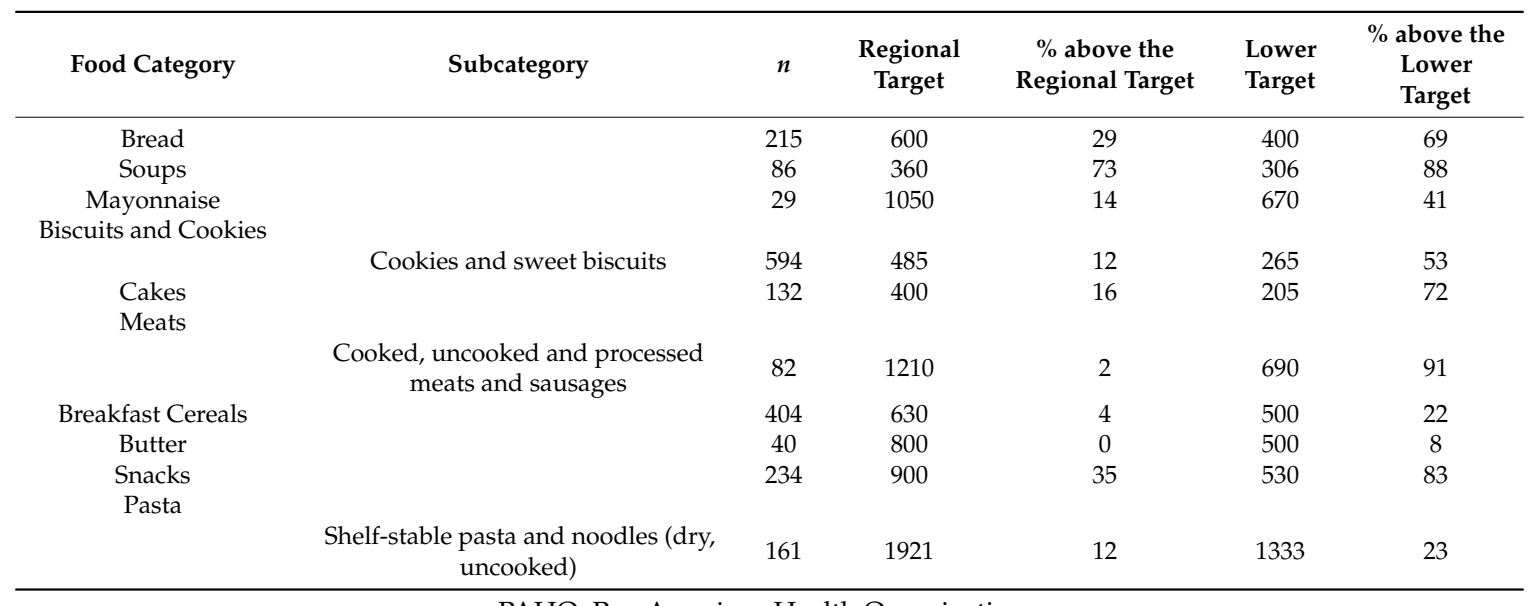

PAHO: Pan American Health Organization.

\section{Discussion}

Many processed food categories contained an excessive amount of sodium. Processed meats (ham, bacon, and sausages) had the highest concentrations. These data are consistent with the SALMEX study that found processed meat was the main contributor to daily sodium intake, representing $8 \%$ of total sodium intake per capita measured by three-day food records [31]. In the sample studied we found that the proportion of foods classified as compliant was lower for international targets (UK FSA and PAHO) compared to the Mexican standards established by COFEPRIS. Finally, to our knowledge, this is the first paper that evaluates and monitors the sodium content of processed foods in Mexico. In general, the maximum sodium content in processed foods established by international (UK FSA) and regional (PAHO) agencies is lower than the levels suggested by COFEPRIS in Mexico. Nevertheless, sodium content in processed foods is high and we should aim to meet the WHO recommendation.

This evidence might encourage the utilization of regional and international targets to monitor and evaluate the progress made by the food industry. As part of the policy package to stop the epidemic of diet-related diseases, like hypertension and cardiovascular diseases, the Mexican food stamp (COFEPRIS criteria) should identify products high in sodium content. Nevertheless, we found statistically significant differences in the proportions of foods complying with FSA targets and COFEPRIS criteria. This might be partially explained by the close participation of the food industry in the design of nutrient profiling systems. In the past, the food industry has been invited to participate in committees that make food policy decisions. A case study recently documented such interference in the profiling system of the Mexican front of package labelling [32].

Since the compliance is easy to meet, the current strategy does not promote food reformulation. The Mexican government could reduce the cut-off points of the nutritional stamp to promote food reformulation by food manufacturers. In this sense, the definition of new maximum levels of sodium in processed food could contribute to the reduction among the Mexican population. In the Mexican adult population, it is known that processed and ultra-processed foods contribute $36 \%$ to total energy [33]; nevertheless, an estimate of how much of the sodium intake these products contribute to the average sodium intake is lacking. In Australia, evidence shows that ultra-processed food provides $40 \%$ of 
sodium in preschool children [34]. In United States, quick service restaurants that mostly serve processed and ultra-processed foods provide $8 \%$ of total sodium in adults diets [35].

Despite the existence of Mexican voluntary targets, experience has proved that without government surveillance and regulation there is not a sufficient incentive for the food manufacturers to reformulate products [36]. Ultimately, mandatory targets for processed foods will be needed to substantially reduce sodium dietary intake across the Mexican population. A gradual transition to stringent profiles such as the PAHO benchmarks is recommended. Setting targets is feasible; a number of countries in the Pan-American region like Argentina, Brazil and Canada have implemented timelines for food reformulation [24]. Besides, existing food technology can help to maintain taste when reducing the sodium content [37]. Furthermore, after the reformulation, it is important to monitor adherence to targets; this monitoring system should be transparent and regularly verified [38]. Public education and social marketing are also needed to motivate the population to choose a healthier diet with a lower sodium content [39]. Afterwards, the demand for low and sodium free products is expected to rise. For example, hypertensive older adults who are conscious about the health consequences of salt had higher willingness to consume low-sodium options [40]. Furthermore, a study documented that the majority of consumers agree that it is a good idea for governments to restrict food manufacturers from putting excess salt in foods [41]. Another strategy with a population approach to reduce sodium intake is the front of package labelling. Uruguay and Chile, for example, have a warning labelling system that is easily understood by the population, which helps consumers make healthier food choices [42]. Besides, Chile's criteria are stringent because it was based on evidence. The implementation of their front of package labelling system had a plan to implement progressive thresholds to move closer to PAHO criteria [11]. The local government of Mexico City has taken some steps toward reducing sodium intake. There is a local strategy that aims to reduce it: The campaign "Less salt, more health," which removed saltshakers from tables of restaurants. In a recent evaluation, 5179 restaurants followed the campaign [12]. One of the limitations of the strategy is that the daily consumption of sodium cannot be tracked; therefore, it is hard to prove that removing saltshakers from tables is effective. Future assessments of this strategy are highly desirable. Another effort is the national agreement to reduce $10 \%$ of the sodium content of bread [13]. This voluntary agreement was implemented during 2012; however, an evaluation of this public health measure has not been conducted.

This study used data taken from the package and labelling of processed foods and does not assess individual sodium intake. In Mexico, the surveillance of food labelling is undertaken by the Ministry of Health along with COFEPRIS. The accuracy of the nutrition information displayed in packages is regularly checked with bromatological studies that assess the food composition in order to verify that the information is consistent with the actual content of foods [43]. Furthermore, open-access food composition data provided by the food industry would simplify efforts to monitor and assess the content of food products and their nutrients of concern. This study was cross-sectional; therefore, it does not evaluate the progress in reformulation. In future studies, data from different years will be needed to assess the reformulation of the nutrition content. Research is needed to assess the national and local initiatives, evaluate the population's sodium dietary intake, and identify the contribution of processed and ultra-processed foods to the diet.

\section{Global Implications}

The estimated mean level of global sodium consumption is $3.95 \mathrm{~g}$ per day. Globally, 1.65 million annual deaths from cardiovascular causes were attributed to sodium intake above the reference level [3]. Since the contribution of sodium comes from processed foods [44,45], setting and aligning targets is a global initiative that could decrease the burden of non-communicable diseases $[10,11$, 46]. A total of 75 countries had adopted a national salt reduction strategy by 2015. Nevertheless, more efforts are needed to support low- and middle-income countries to comply with international recommendations [46]. 


\section{Conclusions}

These data provide a critical baseline assessment for monitoring sodium levels in Mexican processed foods. This assessment will allow for further monitoring of sodium levels and food reformulation. The majority of food groups were found to be high in sodium. Most of them are above the COFEPRIS criteria which are less stringent than the international or regional targets. Processed foods are widely consumed by the Mexican population. Given the health priorities in Mexico, our findings support that strong regulations are needed to reformulate processed foods available in the Mexican market. This measure could have the potential to decrease health risks due to high sodium intake.

Author Contributions: C.N. performed the statistical analysis, and drafted the manuscript. L.T.-M. coordinated the data collection and critically revised the manuscript. E.M.-F. interpreted the data, and wrote results. C.M. provided guidance for the analysis and worked the discussion. E.D.-G. interpreted the data and gave input for discussion. S.B. was responsible for data acquisition, provided the research idea and critically revised the manuscript. All authors read and approved the final version of the manuscript.

Funding: This project was funded by Bloomberg Philanthropies, grant number: 43003, and INFORMAS IDRC, project number 107731-001.

Acknowledgments: The authors would like to acknowledge the fieldworkers who collected the data for this project, Humberto Medina from ITESM for helping to clean the database, and Mariel White for revising the English of the present manuscript.

Conflicts of Interest: The authors declare no conflict of interest. The funders had no role in the design of the study, in the writing of the manuscript, or in the decision to publish the results.

\section{References}

1. He, F.J.; MacGregor, G.A. Salt and sugar: Their effects on blood pressure. Pflugers Arch. Eur. J. Physiol. 2015, 467, 577-586. [CrossRef] [PubMed]

2. Johnson, C.; Raj, T.S.; Trudeau, L.; Bacon, S.L.; Padwal, R.; Webster, J.; Campbell, N. The science of salt: A systematic review of clinical salt studies 2013 to 2014 search strategy and selection criteria. J. Clin. Hypertens. 2015, 401-411. [CrossRef] [PubMed]

3. Mozaffarian, D.; Fahimi, S.; Singh, G.M.; Micha, R.; Khatibzadeh, S.; Engell, R.E.; Lim, S.; Danaei, G.; Ezzati, M.; Powles, J. Global sodium consumption and death from cardiovascular causes. N. Engl. J. Med. 2014, 371, 624-634. [CrossRef] [PubMed]

4. Arcand, J.; Wong, M.M.Y.; Santos, J.A.; Leung, A.A.; Trieu, K.; Thout, S.R.; Webster, J.; Campbell, N.R.C. More evidence that salt increases blood pressure and risk of kidney disease from the science of salt: A regularly updated systematic review of salt and health outcomes (April-July 2016). J. Clin. Hypertens. Greenwich 2017, 19, 813-823. [CrossRef]

5. Campos-Nonato, I.; Hernández-Barrera, L.; Rojas-Martínez, R.; Pedroza-Tobías, A.; Medina-García, C.; Barquera Dr., S. Hipertensión arterial: Prevalencia, diagnóstico oportuno, control y tendencias en adultos mexicanos. Salud Publica Mex. 2013, 55, 144-150. [CrossRef]

6. Stevens, G.; Dias, R.H.; Thomas, K.J.A.; Rivera, J.A.; Carvalho, N.; Barquera, S.; Hill, K.; Ezzati, M. Characterizing the epidemiological transition in Mexico: National and subnational burden of diseases, injuries, and risk factors. PLoS Med. 2008, 5, e163. [CrossRef]

7. World Health Organization. Guideline: Sodium Intake for Adults and Children; World Health Organization: Geneva, Switzerland, 2012.

8. World Health Organization. Global Action Plan for the Prevention and Control of Noncommunicable Diseases 2013-2020; World Health Organization: Geneva, Switzerland, 2013.

9. Webb, M.; Fahimi, S.; Singh, G.M.; Khatibzadeh, S.; Micha, R.; Powles, J.; Mozaffarian, D. Cost effectiveness of a government supported policy strategy to decrease sodium intake: Global analysis across 183 nations. BMJ 2017, 356. [CrossRef] [PubMed]

10. Trieu, K.; Neal, B.; Hawkes, C.; Dunford, E.; Campbell, N.; Rodriguez-Fernandez, R.; Legetic, B.; McLaren, L.; Barberio, A.; Webster, J. Salt reduction initiatives around the world-A systematic review of progress towards the global target. PLoS ONE 2015, 10, e0130247. [CrossRef] 
11. Webster, J.; Trieu, K.; Dunford, E.; Hawkes, C. Target salt 2025: A global overview of national programs to encourage the food industry to reduce salt in foods. Nutrients 2014, 6, 3274-3287. [CrossRef]

12. Boletin Menos Sal, Más Salud. Available online: http://www.salud.cdmx.gob.mx/campanas/menos-salmas-salud (accessed on 10 July 2017).

13. Diario Oficial de la Federación. ACUERDO por el que se Recomienda la disminución del Uso de Sal Común o Cloruro de Sodio en la Elaboración de Pan como una Medida de Prevención de Enfermedades Cardiovasculares, y Otras Crónico-degenerativas. Available online: http:/ / dof.gob.mx/nota_detalle.php? codigo $=5256201 \&$ fecha $=22 / 06 / 2012$ (accessed on 18 December 2018).

14. Peters, S.A.E.; Dunford, E.; Ware, L.J.; Harris, T.; Walker, A.; Wicks, M.; van Zyl, T.; Swanepoel, B.; Charlton, K.E.; Woodward, M.; et al. The sodium content of processed foods in South Africa during the introduction of mandatory sodium limits. Nutrients 2017, 9, 404. [CrossRef]

15. Allemandi, L.; Tiscornia, M.V.; Ponce, M.; Castronuovo, L.; Dunford, E.; Schoj, V. Sodium content in processed foods in Argentina: Compliance with the national law. Cardiovasc. Diagn. Ther. 2015, 5, 197-206.

16. Kraemer, M.V.d.S.; de Oliveira, R.C.; Gonzalez-Chica, D.A.; Proença, R.P.d.C. Sodium content on processed foods for snacks. Public Health Nutr. 2016, 19, 967-975. [CrossRef]

17. Martins, C.A.; de Sousa, A.A.; Veiros, M.B.; González-Chica, D.A.; Proença, R.P.d.C. Sodium content and labelling of processed and ultra-processed food products marketed in Brazil. Public Health Nutr. 2015, 18, 1206-1214. [CrossRef]

18. León-Estrada, S.; Pedroza, A.; Quezada, A.; Flores-Aldana, M.; Barquera, S. Fuentes Dietéticas que Aportan Mayor Contenido de Sodio a la Dieta de los Adultos Mexicanos y Patrones Asociados: Análisis de la ENSANUT 2012; Instituto Nacional de Salud Pública: Cuernavaca, México, 2014; pp. 2-28.

19. Nieto, C.; Rincon-Gallardo Patiño, S.; Tolentino-Mayo, L.; Carriedo, A.; Barquera, S. Characterization of breakfast cereals available in the Mexican market: Sodium and sugar content. Nutrients 2017, 9, 884. [CrossRef] [PubMed]

20. Popkin, B.M. Nutrition, agriculture and the global food system in low and middle income countries. Food Policy 2014, 47, 91-96. [CrossRef]

21. Public Health England. Salt Reduction Targets for 2017; Public Health England: London, UK, 2017.

22. He, F.; Brinsden, H.; MacGregor, G. Salt reduction in the United Kingdom: A successful experiment in public health. J. Hum. Hypertens. 2014, 28, 345-352. [CrossRef]

23. Comisión Federal para la Protección Contra Riesgos Sanitarios. Manual de Etiquetado Frontal Nutrimental. Available online: https:/ / www.gob.mx/cms/uploads/attachment/file/55012/ManualEtiquetado_VF.pdf (accessed on 18 December 2018).

24. Campbell, N.; Legowski, B.; Legetic, B.; Ferrante, D.; Nilson, E.; Campbell, C.; L'Abbé, M. Targets and timelines for reducing salt in processed food in the Americas. J. Clin. Hypertens. 2014, 16, 619-623. [CrossRef] [PubMed]

25. Instituto Nacional de Estadística y Geografía. Encuesta Intercensal 2015. Available online: http:/ / cuentame. inegi.org.mx/monografias/informacion/jal/poblacion/ (accessed on 25 April 2018). (In Spanish)

26. Consejo Nacional de Evaluación de la Política de Desarrollo Social. Rezago Social a Nivel Zonas Urbanas (AGEB urbanas). Available online: https://www.coneval.org.mx/Medicion/IRS/Paginas/Rezago_social_ AGEB_2010.aspx (accessed on 18 December 2018).

27. Mexico News Daily. Comercial Mexicana Sells to Soriana. January 2015. Available online: http: / / mexiconewsdaily.com/news / comercial-mexicana-sells-soriana/ (accessed on 5 March 2018).

28. Rayner, M.; Vandevijvere, S. INFORMAS Protocol: Food Labelling Module. 2017. Available online: https: / / figshare.com/articles/INFORMAS_Protocol_Food_Labelling_Module/5673643 (accessed on 5 March 2018).

29. Kanter, R.; Reyes, M.; Corvalán, C. Photographic methods for measuring packaged food and beverage products in supermarkets. Curr. Dev. Nutr. 2017, 1, e001016. [CrossRef] [PubMed]

30. Campbell, N.; Legowski, B.; Legetic, B.; Nilson, E.; L'Abbé, M. Inaugural maximum values for sodium in processed food products in the Americas. J. Clin. Hypertens. 2015, 17, 611-613. [CrossRef]

31. Colin-Ramirez, E.; Espinosa-Cuevas, Á.; Miranda-Alatriste, P.V.; Tovar-Villegas, V.I.; Arcand, J.; Correa-Rotter, R. Food sources of sodium intake in an adult mexican population: A sub-analysis of the SALMEX study. Nutrients 2017, 9, 810. [CrossRef] [PubMed] 
32. UK Health Forum. Public Health and the Food and Drinks Industry: The Governance and Ethics of Interaction. Lessons from Research, Policy and Practice; UKHF: London, UK, 2018.

33. Marrón-Ponce, J.A.; Sánchez-Pimienta, T.G.; da Costa Louzada, M.L.; Batis, C. Energy contribution of NOVA food groups and sociodemographic determinants of ultra-processed food consumption in the Mexican population. Public Health Nutr. 2017, 21, 87-93. [CrossRef] [PubMed]

34. O'Halloran, S.A.; Lacy, K.E.; Woods, J.; Grimes, C.A.; Campbell, K.J.; Nowson, C.A. The provision of ultra-processed foods and their contribution to sodium availability in Australian long day care centres. Public Health Nutr. 2018, 21, 134-141. [CrossRef]

35. Drewnowski, A.; Rehm, C.D. Sodium intakes of US children and adults from foods and beverages by location of origin and by specific food source. Nutrients 2013, 5, 1840-1855. [CrossRef] [PubMed]

36. Magnusson, R.; Reeve, B. Food reformulation, responsive regulation, and "Regulatory Scaffolding": Strengthening performance of salt reduction programs in Australia and the United Kingdom. Nutrients 2015, 7, 5281-5308. [CrossRef]

37. Allison, A.; Fouladkhah, A. Adoptable interventions, human health, and food safety considerations for reducing sodium content of processed food products. Foods 2018, 7, 16. [CrossRef] [PubMed]

38. Bryden, A.; Petticrew, M.; Mays, N.; Eastmure, E.; Knai, C. Voluntary agreements between government and business-A scoping review of the literature with specific reference to the public health responsibility deal. Health Policy 2013, 110, 186-197. [CrossRef] [PubMed]

39. Johnston, Y.A.; McFadden, M.; Lamphere, M.; Buch, K.; Stark, B.; Salton, J.L. Working with grocers to reduce dietary sodium: Lessons learned from the broome county sodium reduction in communities pilot project. J. Public Health Manag. Pract. 2014, 20, 54-58. [CrossRef] [PubMed]

40. Chau, P.H.; Ngai, H.H.Y.; Leung, A.Y.M.; Li, S.F.; Yeung, L.O.Y.; Tan-Un, K.C. Preference of food saltiness and willingness to consume low-sodium content food in a Chinese population. J. Nutr. Heal. Aging 2017, 21, 3-10. [CrossRef] [PubMed]

41. Patel, S.M.; Gunn, J.P.; Tong, X.; Cogswell, M.E. Consumer sentiment on actions reducing sodium in processed and restaurant foods, ConsumerStyles 2010. Am. J. Prev. Med. 2014, 46, 516-524. [CrossRef]

42. Arrúa, A.; MacHín, L.; Curutchet, M.R.; Martínez, J.; Antúnez, L.; Alcaire, F.; Giménez, A.; Ares, G. Warnings as a directive front-of-pack nutrition labelling scheme: Comparison with the guideline daily amount and traffic-light systems. Public Health Nutr. 2017, 20, 2308-2317. [CrossRef]

43. Diario Oficial de la Federación. NORMA Oficial Mexicana NOM-051-SCFI/SSA1-2010, Especificaciones Generales de Etiquetado Para Alimentos y Bebidas no Alcohólicas Preenvasados-Información Comercial y Sanitaria. Available online: http:/ / dof.gob.mx/nota_detalle.php?codigo=5137518\&fecha=05/04/2010 (accessed on 18 December 2018).

44. Moubarac, J.C.; Martins, A.P.B.; Claro, R.M.; Levy, R.B.; Cannon, G.; Monteiro, C.A. Consumption of ultra-processed foods and likely impact on human health. Evidence from Canada. Public Health Nutr. 2013, 16, 2240-2248. [CrossRef] [PubMed]

45. Monteiro, C.A.; Moubarac, J.C.; Cannon, G.; Ng, S.W.; Popkin, B. Ultra-processed products are becoming dominant in the global food system. Obes. Rev. 2013, 14, 21-28. [CrossRef] [PubMed]

46. Eyles, H.; Shields, E.; Webster, J.; Mhurchu, C.N. Achieving the WHO sodium target: Estimation of reductions required in the sodium content of packaged foods and other sources of dietary sodium. Am. J. Clin. Nutr. 2016, 104, 470-479. [CrossRef] [PubMed]

(C) 2018 by the authors. Licensee MDPI, Basel, Switzerland. This article is an open access article distributed under the terms and conditions of the Creative Commons Attribution (CC BY) license (http:/ / creativecommons.org/licenses/by/4.0/). 